\title{
MUSEU BRANCO OU DECORADO? AMBIENTES PARA ARTE E COMPORTAMENTOS FRENTE ÀS OBRAS
}

\section{RESUMO}

Reflexão sobre as percepções da arte em exibição envolvendo certos esquemas de ambientes museais, que se cristalizaram enquanto modelos de longa duração - period rooms e cubos brancos - para melhor compreender os artifícios de construção de sentidos a partir das obras (de arte) em situação e a relação com formas de comportamento estético e de lugares de memórias para a história da arte.

\section{PALAVRAS-CHAVE}

Ambientação em museus; cubo branco; period rooms; comportamento estético; história da arte.
Marize Malta*

Universidade Federal do Rio de Janeiro

\begin{abstract}
Reflection of perceptions of art on display, involving certain museological environment schemes, which crystallized as long duration models - period rooms and white cubes - to better understand the construction of senses from the location of works (of art) in situations and the relation with forms of aesthetic behavior and places of memories for the history of art.
\end{abstract}

\section{KEY-WORDS}

Museums environment; white cube; period rooms; aesthetic behavior; history of art.

\footnotetext{
* Marize Malta é professora de história da arte/ artes decorativas/ ambiências interiores na Escola de Belas Artes da Universidade Federal do Rio de Janeiro. Graduada em Arquitetura (USU), mestre em História da Arte (EBA-UFRJ) e doutora em História (UFF). Seu domínio de investigação é em história e teoria das ambiências, artes decorativas, arte doméstica, objetos do mal, coleções e modos de exibição.
} 


\section{Dar a ver}

Os museus dão a ver, privilegiam aquilo que exibem e se valem de dispositivos para dar valor aos objetos, ora espetacularizando sua aparição, ora disfarçando sua presença, ou mesmo ocultando-a, na desafiadora missão de manter viva a memória dos testemunhos dos grandes feitos da humanidade (Mairesse; Hurley, 20I2). Encarados como espaços de sacralização, tão potentes como templos, é impossível pensarmos na arte hoje, em suas histórias e teorias, sem considerá-los, sem procurar compreender os meandros das relações institucionais e curatoriais, de seu público e crítica, das ambientações e dos textos de mediação que perpassaram suas trajetórias e auxiliaram a reorientar juízos sobre arte e a rascunhar as narrativas da história da arte.

Vários modelos de ambientes para exibição foram desenvolvidos em épocas distintas para dar conta das contingências epistemológicas possíveis naquele momento e que direcionavam certa compreensão dos objetos que expunham, visto sua finalidade pedagógica preliminar, ou seja, como enquadrar para ensinar. Nossa intenção é refletirmos sobre as percepções da arte em exibição que envolvem certos esquemas de ambientes museais que se cristalizaram enquanto modelos duradouros, no intuito de procurarmos melhor compreender os artifícios de construção de experiências, a partir das obras em situação e de lugares de memória para a história da arte. Nesse sentido, iremos invocar dois modelos de ambientação - as chamadas period rooms e os cubos brancos (O'Doherty, 2002) ou espaços brancos (Klonk, 2009) - de modo a perceber os regimes visuais-corporais que envolvem a experiência de estar em lugares com arte, no caso, os museus, de ver e compreender arte que, por sua vez, entrelaça-se com modos de historicizá-la. Diante dos vários dispositivos de mediação, iremos considerar, como recorte, a relação das obras de pintura com as paredes diante do tratamento das superfícies - cores, padrões, textura; os efeitos da composição (ou mise-en-scène) no ambiente, que podem ter ou não o auxílio de outros elementos, como iluminação e cadeiras, e os pontos de vista oferecidos aos visitantes pelas expografias resultantes.

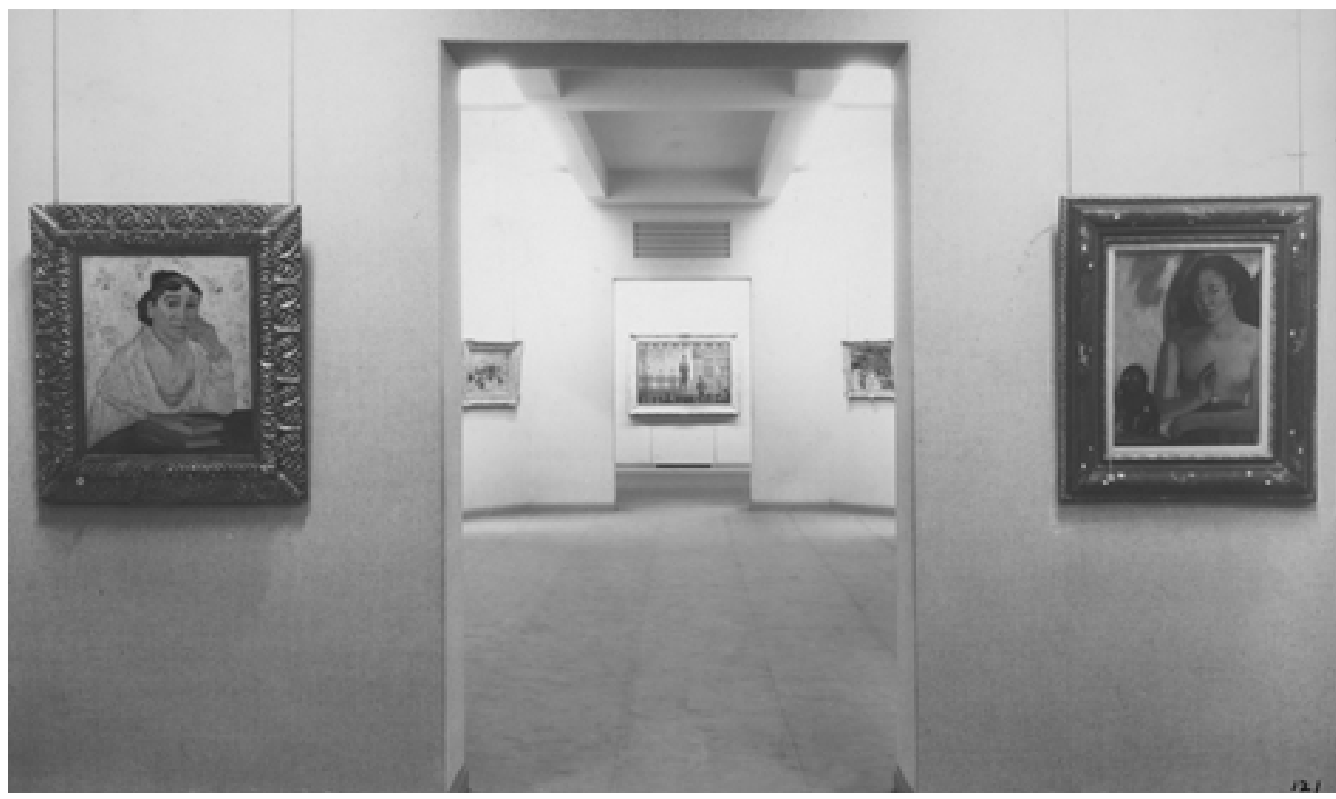

Fig. I. Salões da primeira exposição do MoMA Cézanne, Gauguin, Seurat, van Gogh (MoMA, novembro a dezembro de 1929), ainda localizado no $12^{\circ}$ andar do Heckscher Building, $5^{a}$ avenida com rua 57. Paredes beges em tecido para um fundo homogêneo e neutro. Disponível em: http://www.moma.org/. 


\section{O branco}

Especialmente após Alfred Barr ter utilizado o branco (e o preto) como a melhor cor (valor) de fundo para visualizar a obra de arte (especialmente a geométrica de vanguarda) no Museu de Arte Moderna de Nova York (Klonk, 2009), inúmeras exposições relacionadas à arte moderna consagraram-no como uma solução cromática capaz de configurar um padrão espacial - asséptico, racionalista, inócuo.Aliava-se ao fato de se buscar constituir a ideia de uma "progressão linear e ordenada" com correspondência "à narrativa modernista, que se propunha apresentar a arte como um sistema coerente, que avança em direção a resultados indiscutíveis" (Couto, 20I2:I3). Desse modo, além das paredes em branco, os compartimentos das salas ajudavam a agrupar tendências, movimentos, resultados formais, direcionando leituras e atenções, e também alcançar uma uniformidade desejável, chamada de arte moderna. O fundo branco, contudo, não foi prerrogativa dos museus.

O fundo infinito - grande tecido estendido ou mesmo uma parede em curva pintada de branco - tão empregado nos estúdios fotográficos, sugeria a supressão da ideia da materialidade do fundo, como se não existisse parede alguma, ainda permitindo manejar com segurança a luz mais adequada à exposição do objeto.A estratégia permitia a fotografia alcançar a máxima atenção do observador sobre o objeto posicionado à frente desse fundo. De forma similar, a obra moderna de vanguarda, especialmente a pintura, assumia sua autonomia sobre a materialidade do fundo, por mais que a instituição museal que lhe dava suporte se configurasse de concreto, tijolo e vidro, ou seja, por planos sólidos arquitetônicos.

Antes dos fundos infinitos em branco, os estúdios fotográficos no século XIX se valiam de cenários pintados, fornecendo um fundo imaginário à figura fotografada, que auxiliavam a narrar histórias desejadas, simulando esquemas simbólicos decorrentes da combinação entre tema pictórico do fundo, dos acessórios, da vestimenta e da pose do fotografado e o destino da fotografia (Turazzi, 1995; Mauad, 2008). As práticas dos quadros vivos, dos teatros burgueses e das seculares pinturas de retrato sintetizavam referências para se criar os conjuntos-narrativas mais eficazes para o retrato fotográfico. Com isso, podemos perceber o quanto os campos são permeáveis a práticas e referências de outros dispositivos visuais, enfraquecendo a ideia de sua autonomia e nos alertando para considerar as interpenetrações dos vários esquemas visuais, ambientais e mentais nas práticas do vivido, fazendo com que as imagens dos interiores de retratos em estúdio dialogassem com as imagens interiores de museus, de casas, exposições universais, cafés, espetáculos teatrais, lojas de departamentos e passagens (Benjamin, 2009).

Considerando o estúdio fotográfico do século XIX, podemos refletir que cenário, indumentária e acessórios eram importantes fatores para construir a narrativa-visual e desenvolver a representação do teatro da memória que assegurasse futuras lembranças (Meneses, 1994: 9). Assim também funcionavam os interiores domésticos oitocentistas que, com suas milhares de informações materiais e visuais, procuravam criar um cenário que harmonizasse com a personalidade do personagem, representasse-o para os outros e ainda fosse capaz de fazer lembrá-lo na posteridade (Malta, 20II). Muitas ambientações de museus seguiram essa prerrogativa, mas com objetivo de causar impacto na coletividade, dissolvendo questões personais, engendrando situações que alimentassem um reconhecimento de afã nacionalista, as quais se valeram da potência decorativa que permitia ao visitante estar imerso em um espaço criado para rememorar épocas e circunstâncias ou mesmo criar memórias (Haskell, 1993: 279-303). 
Os marcos visuais de semântica historicista auxiliaram a demarcar os fatos importantes de serem lembrados pela coletividade, fazendo com que a arte fosse um potente fio condutor para narrar as histórias nacionais. Lembremos das encomendas feitas aos artistas para as grandes galerias do Museu de Versalhes (Poulot, 2013:39-40), o Museu Nacional Alemão de Nuremberg (Haskell, 1993 : 283-287) e as decorações projetadas por Affonso Taunay para o Museu Paulista (Mattos, 2003). Assim, a pintura decorativa funcionava como símbolo dos momentos de glória da nação ou do estado.

Para além do objetivo de representar a pátria, outros museus se prontificaram a representar o mundo, caso dos museus universais, que buscaram reunir os feitos da humanidade em um só local, como um espaço de utilidade pública. Como afirma Monica Preti, "A mise-en-scène dos objetos visa apresentar uma Grande Narrativa: a ideia de uma civilização como processo que se desenvolve através da história dos povos" (Preti, 20I5: 7). A partir da reunião de testemunhos materiais de diferentes culturas, sua acomodação deveria ser pensada em situações de encenação, em uma ambientação capaz de favorecer o entendimento do visitante sobre sua importância.A ideia de mise-en-scène implicava criar um artifício que convencesse da ficção narrada.

As negociações entre o que era mostrado e escondido, o que era olhado e imaginado, os níveis de atenção requeridos, a postura para a experiência da percepção e a construção de sentidos desenvolveram-se em grande escala no século XIX (Crary, 2000), irradiando tanto no lado de dentro das casas quanto de outros espaços interiores, favorecendo uma cultura visual de olhar de dentro e para dentro, uma verdadeira emergência da potência do espaço interior (Rice, 2007). Muitas vezes esse interior, um espaço envolvente de objetos, esteve relacionado com a ação de trazer coisas para dentro e por domesticar a realidade (Harbison, 2000: III), pertinente com a consideração quase exclusiva do espaço interior enquanto habitação.Vale lembrar que a autonomia dos interiores esteve atrelada ainda à eclosão de outras tipologias, como foyers, lojas de departamento, teatros, restaurantes, no caso, lugares de lazer, prazer, desejo e consumo (Sparke, 2008), onde a decoração também formulava modos de olhar e de comportar-se. Esse apelo ao decorativo permitia travar diálogos entre as esferas de dentro e de fora, da casa e demais espaços interiores, e interpenetrar práticas decorativas, diluindo a noção de independência e limites rígidos, chegando igualmente ao museu.

O interior, fortemente impregnado pela decoração (de interiores), encobria os suportes arquitetônicos, fazendo eclodir uma imagem independente, autônoma, cujos objetos, estampas e texturas eram os responsáveis por dotar o ambiente de um caráter (fig. 2), o oposto do que, gerações mais tarde, a arquitetura modernista de vanguarda preconizaria, sublinhando o valor do espaço e não das coisas no espaço. Para essa contraposição, foi necessário eliminar as estampas, texturas, os muitos objetos e buscar uma essencialidade quantitativa para que fosse possível perceber mais o vazio do que o cheio, mais os limites do espaço (a arquitetura) do que aquilo que o preenchia (os móveis e demais objetos), sem deixar vestígios de hierarquias (quais os cômodos eram mais importantes que outros). Desejava-se um purismo arquitetônico e o branco foi o valor cromático que assumiu preponderância nos edifícios de vanguarda.Também os museus com arte moderna não demorariam a assumir suas paredes em branco.

Repercussões e reverberações positivas da curadoria de Alfred Barr para - MoMA transformaram a expografia "de fundo neutro" em um modelo exemplar (de caráter masculino) (Klonk, 2009: 15I). Passava-se a acreditar que o espaço mais adequado para se expor uma obra de arte (primeiramente de 


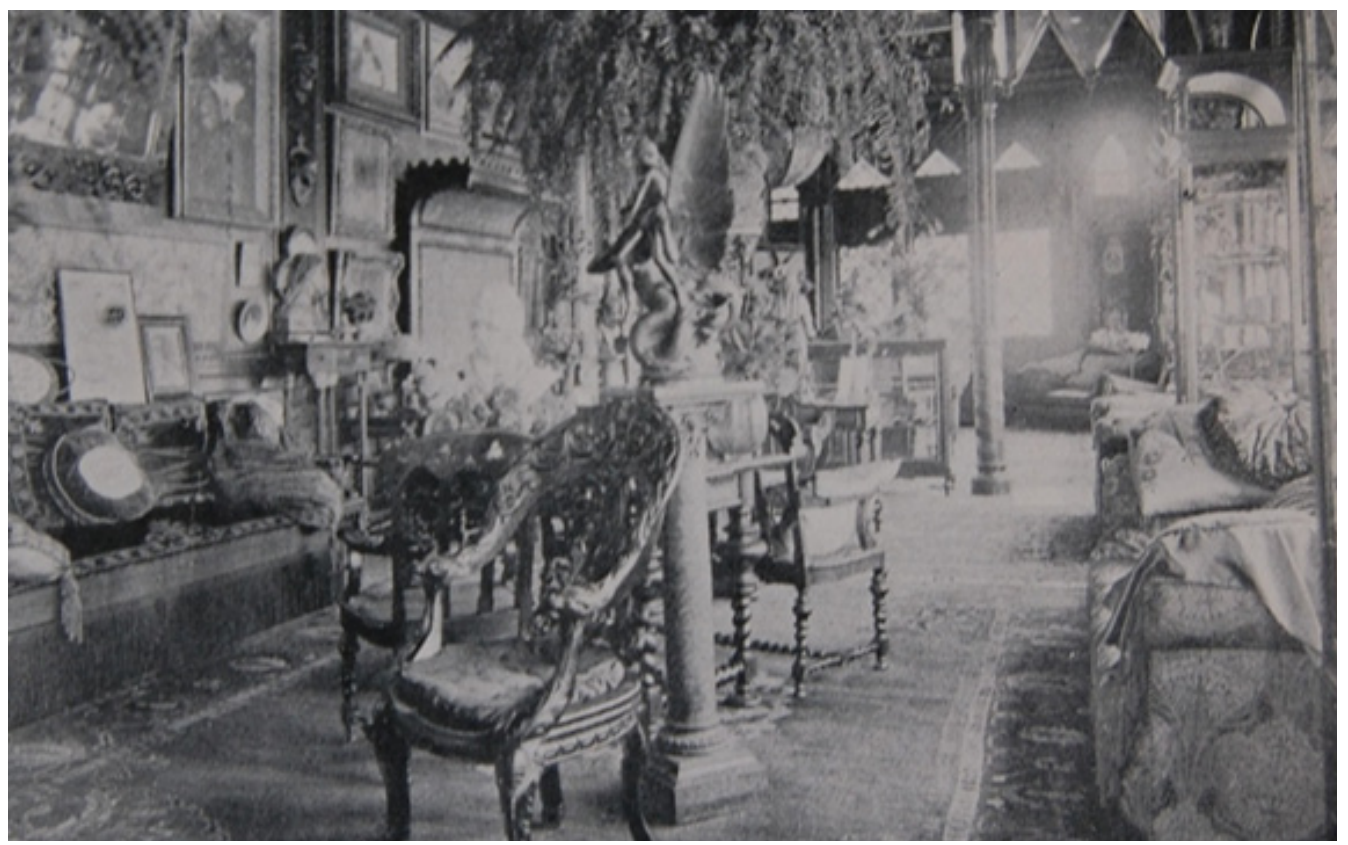

Fig.2. Os ambientes de gosto oitocentista, a densidade decorativa e a incorporação (domesticação) dos objetos pelo interior. Salão da Villa Murtinho, solar da sra. Santos Lobo. Fonte: Revista da Semana, Rio de Janeiro, n.33, 13 agosto de 1921 .

caráter moderno de vanguarda) era o ambiente circunscrito de um espaço em branco porque deixaria que apenas as obras assumissem protagonismo e não precisassem interagir com a arquitetura e a decoração, aproximando os salões do museu da situação dos estúdios fotográficos com seus fundos infinitos em branco que isolavam o objeto ou a pessoa do mundo contingencial.

\section{Period rooms}

Os espaços internos dos museus-em-branco se distanciavam das alusões historicistas, situação comum em muitos museus de arte do passado, como por exemplo, o Museu de História da Arte de Viena (Kunsthistorisches Museum), edificado entre 1872 e 189I a partir de projeto de Gottfried Semper e Karls Freiherr Von Hasenauer. As salas que abrigavam acervos da antiguidade eram decoradas a partir do repertório ornamental compatível com o caráter da arte que abrigavam: decoração egípcia para abrigar peças antigas do Egito; decoração romana para ambientar objetos da arte romana.... O modelo já havia sido testado por Alexandre Lenoir no Museu dos Monumentos Franceses (I795-I8I6), em que se reproduzia o mais fielmente possível a atmosfera da época correspondente às obras expostas (Glicenstein, 2010: 23-23). A decoração, assim, auxiliava a ambientar as peças originais, criando um recinto condizente estilisticamente, que harmonizasse a figura - a obra - com o fundo - pisos, paredes e teto dos ambientes internos do museu. $\mathrm{E}$, desse modo, o lugar oferecia repertório visual para auxiliar a restituir memórias de acordo com as direções visuais expostas.

Apesar de o esquema não ter sido regra, a simulação estilística ou criação de atmosfera procurava deixar o observador imerso em um espaço harmonizado com o que acolhia e exibia, enfatizando o aspecto informativo-decorativo, pois "A transformação do objeto em peça de museu supõe sua integração pensada ao espaço onde se elabora um saber (...), o da história da arte” (Preti, 20I5: II). Ao se adentrar na sala sobre arte egípcia, a decoração ativava a imaginação de modo a se pensar que não se estava mais em Viena, mas no palácio de um 
faraó, promovendo deslocamento da imaginação. A pintura decorativa também auxiliava a complementar as "falhas" do acervo. O ideal instrutivo dos museus universais oitocentistas lidava com o desafio de narrar histórias com auxílio da simulação, a partir da exibição de obras originais. Assim, o ambiente simulado envolvia as peças autênticas, criando uma tensão entre ficção e verdade. $O$ coroamento dessa prática ocorreu nos Estados Unidos, quando foi criada uma edificação (com partes de 5 claustros medievais franceses) e jardins para abrigar a coleção de arte medieval, o The Cloisters, inaugurado em 1938, recriando uma atmosfera que replicava os tempos medievais (Labbate, 2007:10-20).

Princípio similar pode ser encontrado nas chamadas period rooms, prática que obteve repercussão intensa e duradoura na reconstituição de interiores residenciais de época, com revestimentos, móveis, objetos originais e/ou simulados, como o quarto do rei Francisco I, no Hôtel de Cluny, realizado a partir da concepção do colecionador Alexandre du Sommerard, em I832 (Poulot, 20I3: 39). O Museu Carnavalet, destinado à história da cidade de Paris, segundo concepção de Haussmann, deveria conter "imagens do interior das habitações, espécimes de mobiliário e de utensílios domésticos [expostos] de acordo com séries cronológicas, fazendo sobressair suas diferenças e seus progressos em diversas épocas" (Ibid.: 50). Essas ambientações rememoravam a arte nos palácios e de um público seleto que podia admirá-las in situ.

$\mathrm{Na}$ Europa, os museus ingleses e alemães incorporaram muitos desses artifícios de rememoração de casas dos outros - tempos e pessoas, criando "salas atmosféricas" ou ensembles, que elegiam ambientes de passados próximos de pessoas que não faziam parte da nobreza e podiam ser considerados exemplos de seus antepassados. Nos Estados Unidos, os esquemas de period rooms encontraram grande disseminação nos museus, especialmente naqueles que tratavam de arte americana, o que pode ser observado, em Nova York, tanto no Museu de Arte Metropolitano (MET), quanto no Museu do Brooklyn, sendo o MET o pioneiro em apresentar na Ala Americana, aberta em 1924, os interiores históricos como sua principal atração (Duncan, 2002: 13). Os ambientes detalhadamente montados funcionavam como quadros vivos (sem pessoas), passando a sensação que os moradores estavam prestes a voltar e surpreender os visitantes a olhar para seus espaços domésticos (fig. 3). O quadro morava lá.

Mais do que a perspectiva de encenação, os objetos se contextualizam nos seus usos aparentes. $O$ quadro se harmoniza com parede, cortinas, portas, com móveis e objetos. Ele pode estar em companhia de outros quadros, compartiIhando a atenção. Normalmente, os cenários de época atraíram receptividade entusiasmada do público que se reconhecia em algumas das situações domésticas apresentadas, mas igualmente foram criticados por estarem em museus de arte, enquanto deveriam estar em museus históricos, pois os objetos que compunham as ambiências não podiam ser destacados individualmente (Montebello, 2004), perdendo sua capacidade de serem coisas com atitudes (Attfield, 2000: 12-16).

Além dos núcleos localizados em seções de grandes museus, a prática encontrou nos museus-casa lugares privilegiados para experimentação museológica e expográfica. Nos Estados Unidos, a fazenda de George Washington, em Mount Vernont, na Virgínia, foi a primeira casa a ser adquirida em 1860 para se tornar museu (West, 1999). No Brasil, somente em 1924 seria comprada a casa de Rui Barbosa, primeiro museu-casa do país, inaugurado em 1930 (Malta, 20I2). O Museu Imperial, um representante do período imperial, só seria aberto ao público em 1943.

Raramente os museus-casa foram criados com todos os seus interiores intactos, deixados exatamente como eram por seus últimos moradores, dificul- 
tando sustentar a noção de "interiores autênticos"| (Bastos; Franco, 20l4). Muitos objetos denominados de uso cenográfico auxiliavam a compor o ambiente e dar-lhes o caráter de veracidade. Objetos como esses estavam distantes de serem representantes originais da casa, sendo réplicas ou peças autênticas da época de outra casa ou de outra família, mas eram competentes no poder de comunicação com o público, com situações próximas ao seu cotidiano e na encenação de modos de uso dos objetos, inclusive os de arte, em casa (fig. 4). Eles deveriam estar em condições de dizerem de seus usos sem legendas, dispostos de tal modo que explicitassem porque estavam ali e como serviam aos moradores nas suas múltiplas funções (semânticas, sintáticas e estéticas). Os quadros nas paredes eram partícipes da decoração e as paredes possuíam uma estética própria (figs. 3 e 4 ).

O trabalho de remontagem desses interiores de época envolvia uma espécie de arqueologia doméstica, procurando a partir dos vestígios materiais deixados ou doados reconstituir modos de habitar e usar os espaços. Mas a reconstituição é uma farsa, pois a period room não é uma réplica, mas um simulacro, uma cópia exata de um original que nunca existiu. $O$ passado é transformado em sua própria imagem (Shanks; Tilley, 1992:79). Na simulação, a definição do que é artístico e do que é decorativo não é clara e aquilo que pode ser considerado obra de arte está em uma posição que não favorece sua atuação enquanto sujeito, na medida que integra um conjunto, o ambiente, que passa a ser o sujeito: um ambiente com arte, um ambiente de arte, um ambiente artístico, seja como for. Porém, no século XIX e em boa parte do século $X X$ os ambientes não eram vistos como artísticos, mas lugares para abrigar as obras de arte, cabendo somente aos objetos a possibilidade de serem enquadrados como arte nos museus de arte.

Diferentes de museus históricos, museus de artes decorativas e de design que se utilizavam dos objetos para rememorar uma determinada cultura, a partir de sua materialidade, as coisas incorporadas na museografia dos museus-casa, ou period rooms, eram de certo modo subestimadas em relação ao valor intrínseco, pois o que interessava era a potência para construção da ambiência, seu valor relacional. Por mais que se pudesse chamar a atenção para uma ou outra peça, destacando-a no contexto, o que importava era a capacidade de convencimento de estar no lugar certo e sendo peça necessária para a efetivação do teatro da memória do ambiente, auxiliando-o a tornar-se vivo, ou revivido.

A questão da autenticidade de um ambiente interior, uma espécie de congelamento do programa decorativo de determinado espaço (Bastos; Franco, 2014:69) era quase uma utopia, sendo mais plausível a ideia de uma "restituição mimética" (Poulot, 2013: 39). Para Shanks e Tilley, os ambientes remontados funcionavam feito uma mercantilização do passado, como se ele estivesse disponível para compra (1992: 79), posição que toma o museu como lugar de coisas e cujos dois extremos seriam a loja de departamento e o túmulo, pondo as coisas à venda ou sepultando-as, como último destino (Harbison, 1988). Nessa relação entre objeto e lugar, o museu funcionava como instituição de enquadramento, que ora oferecia ao consumo visual os objetos do acervo, ora sacrificava-os aos esconderijos das reservas, forçando seu esquecimento. Mas, antes de tudo, o museu era tomado como lugar de objetos e não de ambientações, apesar de serem elas que ofereciam formas de visualizar os objetos, uma forma de decoração (de interiores).

'Interior autêntico, segundo Celina Bastos e Anísio Franco “(...) pressupõe a preservação de um programa decorativo que, na sua totalidade, se conservou intacto no espaço original para o qual foi concebido" (Bastos; Franco, 2014: p.69). 


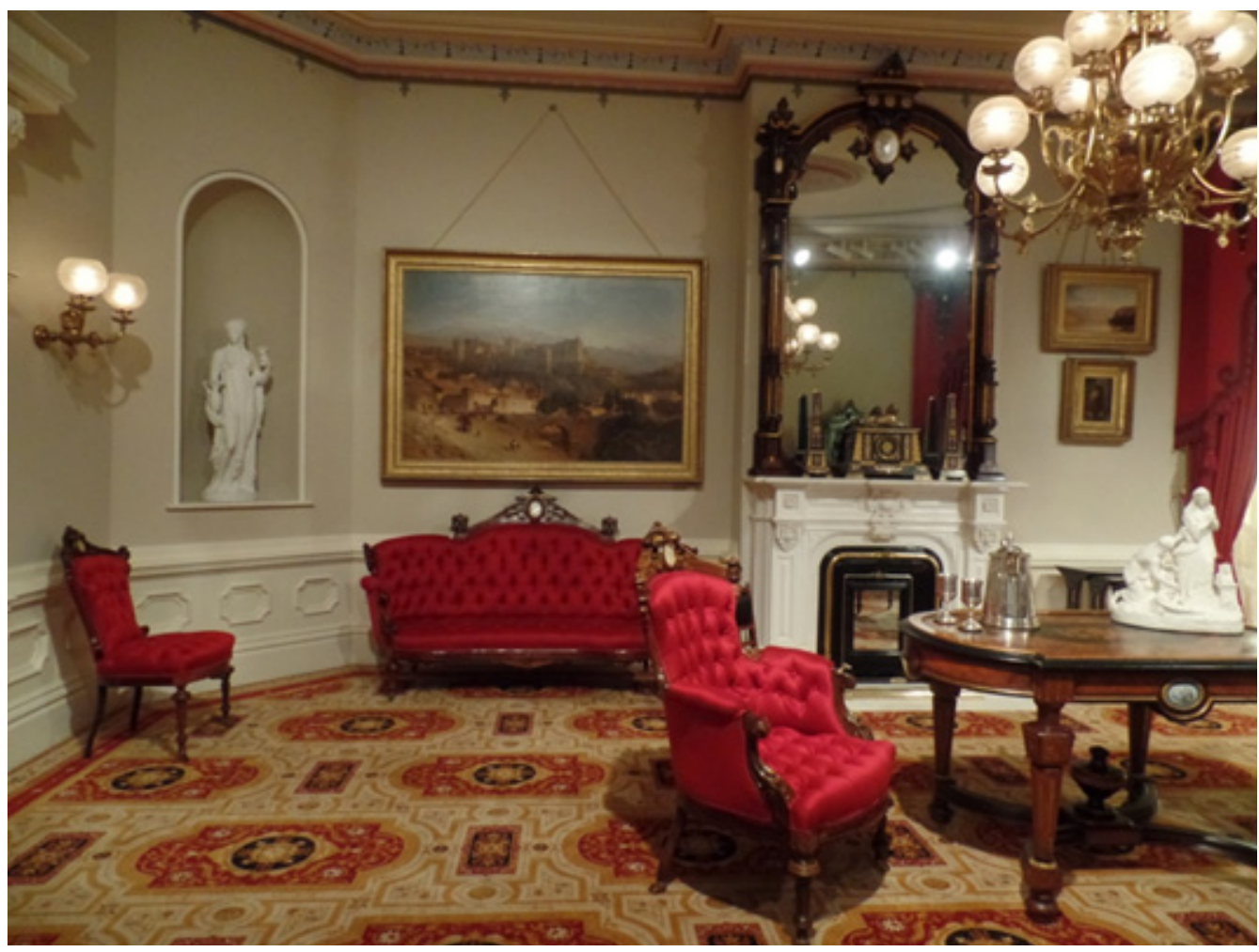

Fig.3. Salão em estilo neo-renascentista. Meriden, Connecticut, Estados Unidos, 1868-70. Period room no Metropolitan Museum of Art, Nova York. Fotografia da autora, 2016.

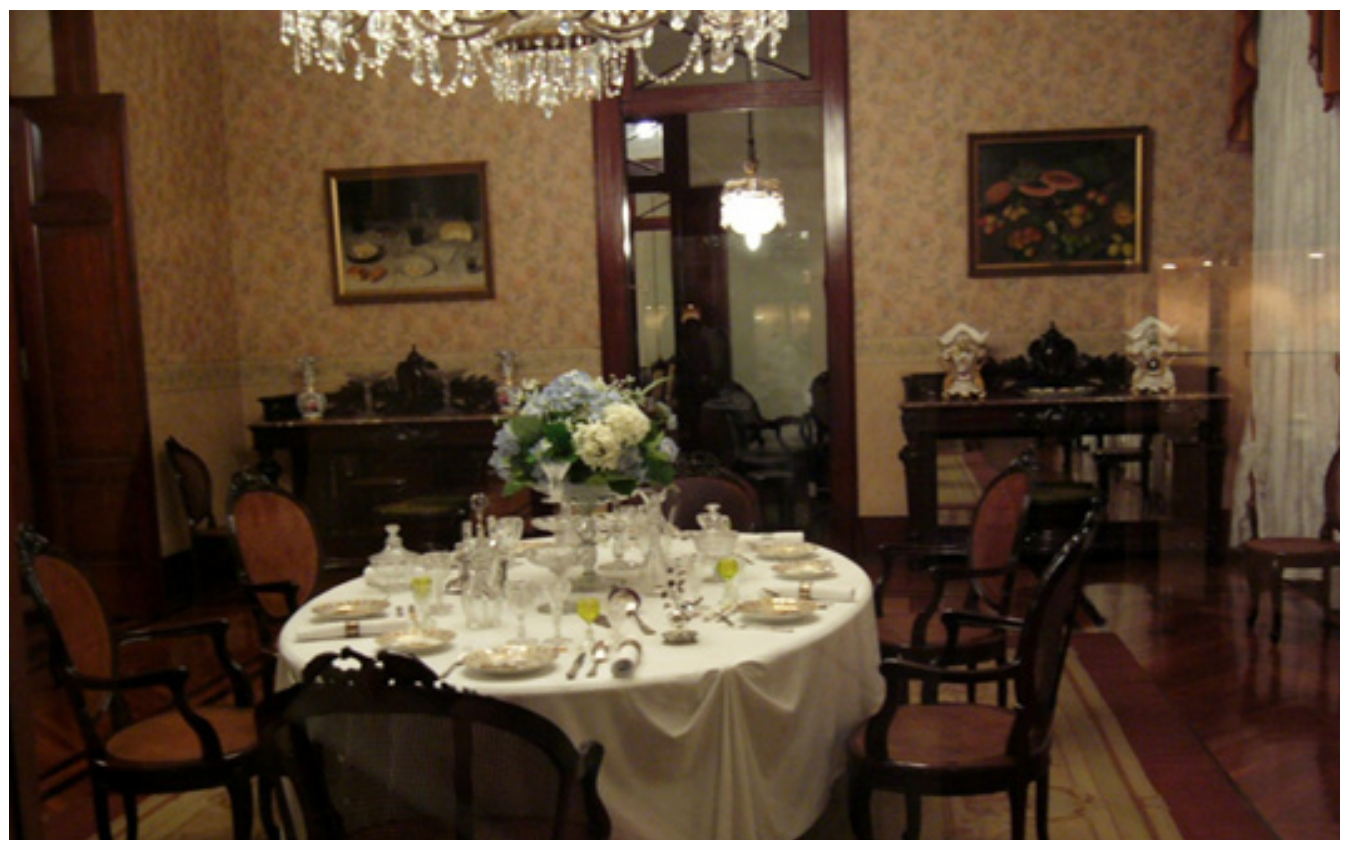

Fig. 4. Reconstituição de sala de jantar do Segundo Império. Museu Imperial de Petrópolis, RJ. Fotografia da autora, 2006. 
O cenário do teatro da memória assemelha-se, na prática, com a decoração de interiores, atuação tomada de modo inferior àquilo que é artístico (percebido, por exemplo, na expressão "meramente decorativo") e bastante relacionado com o gosto pessoal que, no caso das museografias de museus-casa, parece envolver preferências da equipe envolvida ou do responsável pela orientação da expografia. Ou seja, muitas ambientações de museus-casa teriam passado pelo crivo do gosto pessoal daquele que iria decidir o que colocar, onde e como, no sentido de algo próprio e pertinente com o que é da natureza do decorativo. Isso implica entender o sentido decorativo como pessoal, sendo algo que é pertinente ao gosto individual, situação supostamente inversa ao do curador ou do diretor do museu, que proporia a ambientação das obras para além de sua pessoalidade, perseguindo uma cientificidade e uma neutralidade ou um ambiente ideal para obras, guiado por uma problemática estética.

\section{Neutralização}

Os ambientes de museus-casa ou period rooms, entretanto, dificilmente eram adentrados e sim vistos de fora, reforçando a ideia de cenário, de teatro da memória para rememorar um cômodo que fora habitado por certas pessoas de determinada época e lugar. Como uma "magnífica encadernação" (Poulot, 2013: 39), não se adentra pelo livro, mas folheiam-se páginas, percebendo as letras, figuras e desenvolvendo a leitura da sua narrativa.A situação distanciava o público de um envolvimento legítimo, pois a ação expositiva de visibilidade à distância preponderava, reforçando uma preocupação de ordem instrutiva e menos de experiência, como se aqueles móveis, castiçais e bibelôs ao se adentrarem pelo museu tivessem que ser embebidos por uma camada de neutralização, dos seus usos originais, certamente, mas em especial das relações afetivas com que estiveram envolvidos e impossibilitando-os de propiciarem outras convivências. Os ambientes se transformavam em imagens para serem vistas, a exemplo dos quadros de gêneros, só que "pintados" em três dimensões. $O$ ambiente decorado de um lugar, ao se transformar em period room, perdia seu valor espacial de envolvimento, transfigurando-se em cenário, em quadro, em lugar de neutralidade.

A questão da neutralidade que o museu imporia às obras não foi prerrogativa dos museus modernistas. Quatremère de Quincy, nos idos das primeiras décadas do século XIX, propôs uma reorganização do Museu do Louvre (Quincy apud. Preti: 19), orientando para que as obras guardadas em reserva voltassem ao seu lugar de culto, restituindo-as às igrejas de Paris. Tal procedimento compensaria "os riscos de neutralização das obras que o ideal de um grande museu didático comportava (...), de conjurar a ameaça de um cemitério das artes onde 'todos os objetos perderam seu efeito ao perder sua motivação" (Preti:19). Nesse caso, a potência da obra se neutralizava em favor de uma didática museal, que distanciava a obra da memória de sua procedência, dos seus efeitos e das paixões provocadas. $O$ objeto, no processo de musealização, enfrenta uma reconfiguração, ou refuncionalização (Pomian, 1984), que para Quincy enfraquecia suas prerrogativas originais, pois o novo ambiente em nada lembrava seu lugar original, reforçando a ideia de mito de origem e autenticidade.

Para o modelo cubo branco, o processo de neutralização da referência da procedência original potencializava a atuação do objeto sobre o público, "inegavelmente" uma obra de arte. Também outros artifícios foram empregados para reforçar, no cubo branco, a neutralidade do espaço e amplificação dos efeitos das obras sobre a percepção do público. As próprias molduras das telas, tão 
comuns e rebuscadas, pesadas e impactantes, frequentes até fins do século XIX, foram se adelgaçando, simplificando ou mesmo desaparecendo, de modo a que só a tela captasse a atenção. Assim, o sentido de concretude sublevava-se em favor da potência da imagem.

Antes, as rebuscadas molduras, por vezes, bem largas, funcionavam como um alerta, ou um enquadramento para uma janela que descortinava cenas para além do cotidiano, separando os mundos da trivialidade e da imaginação. Nos ambientes interiores carregados de estampas e cores dos palacetes e mansões, as molduras ajudavam a captar a atenção para o que circundavam, buscando apartar os apelos visuais que transitavam em sua volta. A moldura, objeto de prestígio, estabelecia uma divisão entre áreas artísticas (a imagem circunscrita) e decorativas (o tratamento da parede), apesar de a moldura estar normalmente mais comprometida com o esquema decorativo do ambiente. $\mathrm{O}$ argumento de que a moldura seria uma extensão da tela convenceu alguns artistas a nelas interferir, pintando-as ou desenhando-as, como fizeram Whistler ( $\mathrm{Ca}$ price in purple and gold: the golden Screen, 1864 - Freer/Sackler Museum -Washinghton, DC) e Seurat (Evening, Honfleur, 1886 - MOMA-NY), passando a ser desígnio do pintor e não mais do moldureiro, do decorador ou do cliente. $A$ tendência reforçou a postura de enfatizar a autonomia do pintor em relação à sua obra. Contudo, os museus de arte procuravam, por outro lado, reforçar sua autonomia frente à individualidade do pintor, propondo uma ficção que se utilizava de obras de arte para seu proveito (Glicenstein: I3), dirigindo também certos comportamentos ao público visitante.

\section{Onde sentar?}

Diferente dos interiores oitocentistas, repletos de móveis cobertos e recobertos com acolchoados e têxteis, nos quais os moradores deixavam rastros (Benjamin, 2009) e podiam assumir diversos pontos de vista para ver as obras nas paredes, a ideia da assepsia dos museus-cubo-branco procurava confirmar um observador neutro, cujas questões de gosto, subjetividade e pessoalidade eram transferidas exclusivamente para a experiência com a obra, impedindo que o espaço atuasse de coadjuvante e, assim, não permitisse absorver marcas de sua presença, presença atuante. Isso equivaleria a dizer que o cenário era suprimido para que a atuação da obra-ator fosse priorizada e que a marca deixada pela experiência estética fosse canalizada exclusivamente pela obra sobre a subjetividade do espectador.

A ausência ou escassez de assentos nas galerias dos museus cubo-branco², e mesmo dos contemporâneos, confirmam o desejo de não se oferecer superfícies passíveis de receberem impressões (físicas e simbólicas) dos visitantes. Muitas vezes, quando os assentos existem são construídos de material sólido, visualmente limpos e de formas sintéticas, incapazes de absorverem marcas. Alguns assentos são destinados apenas aos vigilantes, localizados estrategicamente para que possam cuidar da segurança do maior número possível de obras (figuras 5 e 6). O visitante deve se concentrar nas obras e para isso ficar em pé por muito tempo, como se seu corpo fosse um receptáculo móvel para o olho e o salão-galeria um teatro fixo para se assistir (Fuss; Sanders, 2012: 65)

\footnotetext{
${ }^{2}$ Cabe salientar que o modelo do museu cubo-branco em termos de assentos, pode ser incorporado em museus de outras tipologias. É comum vermos museus mais antigos, como o Louvre e o Museu do Brooklyn, por exemplo, assumirem a prática de assentos rígidos ou pouco número de bancos para os visitantes, diferente das representações de salões de museus no século XIX onde a presença e quantidade de assentos era mais frequente.
} 

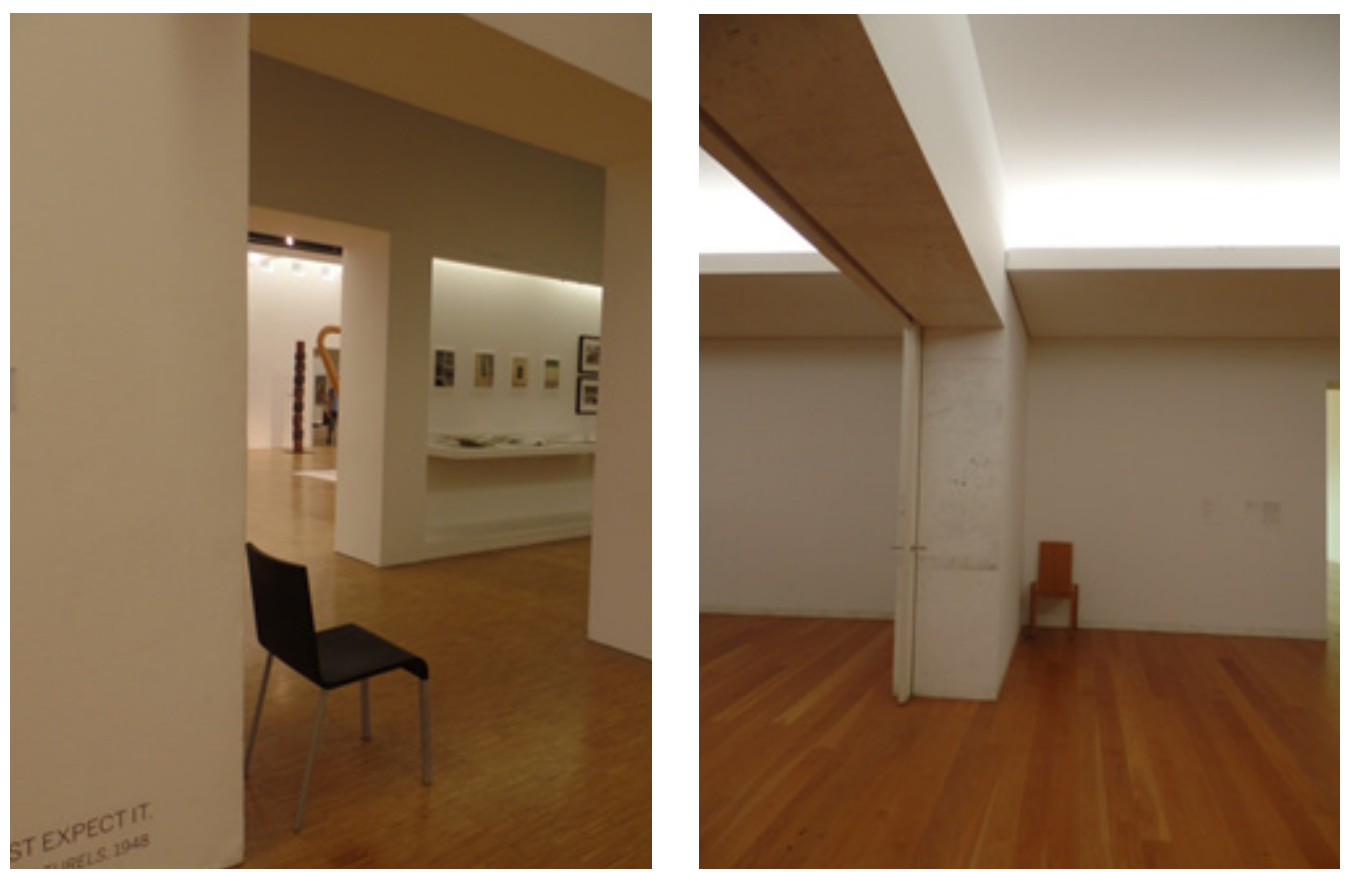

Fig. 5 - A cadeira em frente à parede branca.A cadeira do vigilante, em plástico rígido e alumínio, em um dos salões do Centro Georges Pompidou, Paris. Fotografia da autora, 20।4. Fig. 6. Em um canto, discreto. Cadeira em madeira para vigilante. Fundação Serralves, Porto. Fotografia da autora, 2014.

A posição sentada, uma certa posição de conforto, além de colocar o observador em outro ponto de vista não ideal, tiraria sua atenção/tensão sobre as obras. Ao sentar, o visitante se distancia das obras (os assentos normalmente ficam ao centro da sala) e pode até dar as costas para algumas. Ele percebe o todo, analisa aspectos do salão-galeria, sua decoração, observa as disposições das obras, olha com vagar outros visitantes, constata a luz que incide, confere o efeito da temperatura sobre seu corpo, dá asas à imaginação, e, por consequência, diminui o efeito de cada obra, isoladamente, sobre si (fig. 7).

De certo que existem salas de museus com uma única obra em que é possível a concentração do observador com exclusividade, como Les Nymphéas, de Claude Monet, no Musée de l'Orangerie, para ficarmos com um exemplo emblemático, e que neste caso é comum encontrarmos bancos para permitir uma experiência visual alargada no tempo. Porém, essa não é a situação mais frequente de se encontrar nas ambientações tradicionais em que presença de muitas obras em mesmo ambiente tornou-se padrão. Lá quase não há assentos.

Cabe lembrar que muitos museus nos oitocentos ofereciam sofás aos visitantes que podiam confortavelmente descansar e se aliviar do que o escritor Henry James denominava de “dor de cabeça estética”. No romance The American, o personagem, em pleno Salon Carré no Louvre, aconchegava-se no grande sofá circular e se distraía com as moças que copiavam obras, como sugerida pela tela de Giuseppe Castiglione (fig. 8). O museu oferecia um lugar para conquista - para ver e ser visto - e aonde o personagem ansiava encontrar sua futura esposa. O assento, assim, funcionaria de distração à principal atividade museal em questão: apreciar arte (fig. 9). Por outro lado, os sofás nos primeiros museus funcionavam como dispositivos para promover interação social, contribuindo para cativar um público particular (Fuss; Sanders, 2012: 66). O sofá, a partir dessa prerrogativa, poderia ser impregnado com as memórias de seus usuários, assumindo a relação tátil com capacidade de transmitir as sensações do sujeito que olha sentado em um sofá diante das obras de arte. 

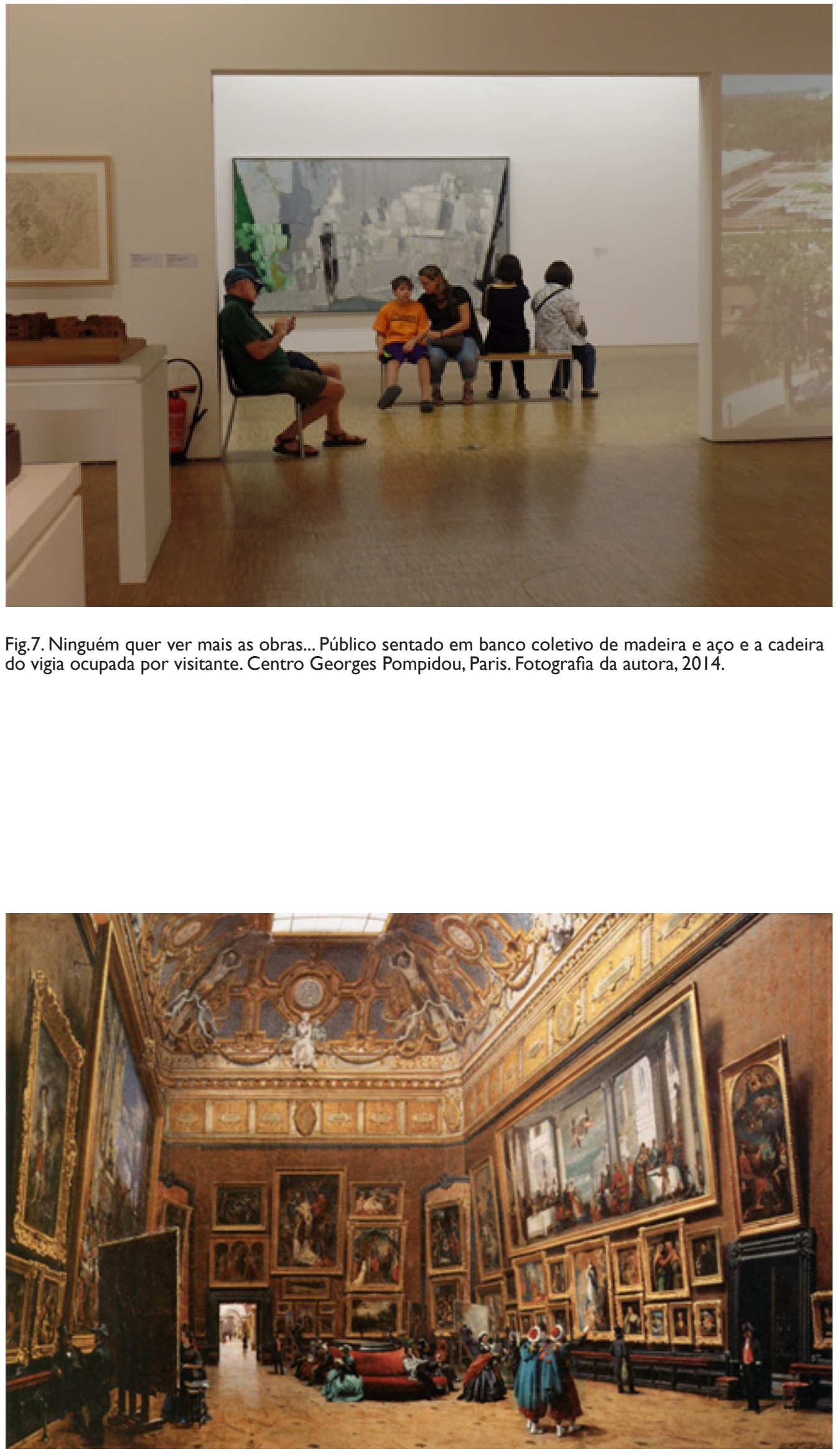

Fig. 8. Giuseppe Castiglione. Le Salon Carré au Musée du Louvre, 1861, ost, 69 x $103 \mathrm{~cm}$. Museu do Louvre, Paris. 


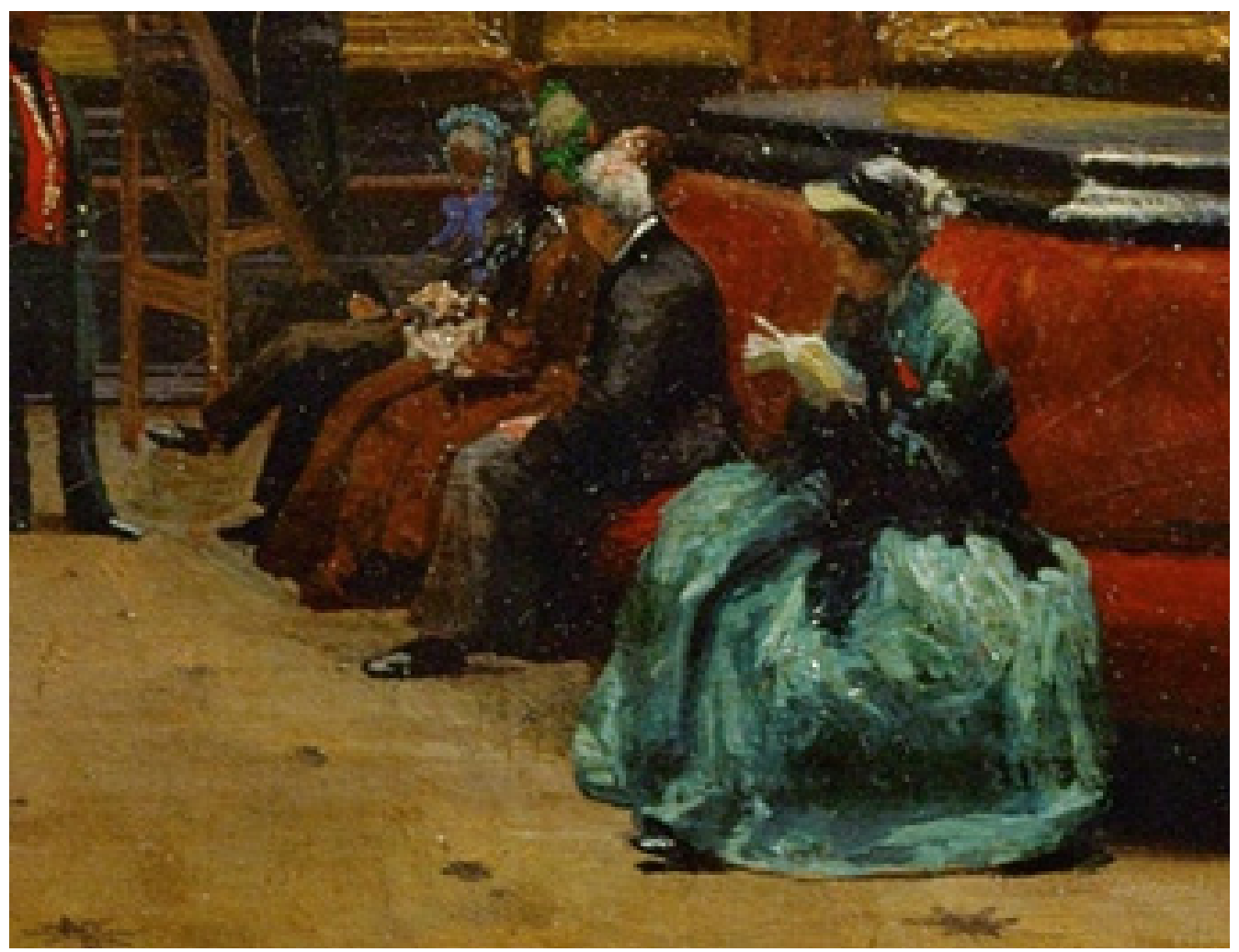

Fig. 9. O sofá e os visitantes no museu. Detalhe da tela acima de Giuseppe Castiglione.

Se considerarmos, de acordo com Ricouer, que lembranças estão intrinsecamente associadas a lugares (2007: 58), os cubos brancos seriam incapazes por si só de serem refúgios de memória, especialmente porque a modernidade de vanguarda procurava no seu discurso romper com os elos do passado, sem o desejo proposital de instituir o passado no presente, e sim projetando o presente para o futuro e, portanto, sem referências onde lembranças pudessem se acomodar. $O$ fundo branco, que gerava a noção de não-lugar, atribuía exclusivamente ao acervo exposto, às obras de arte, a possibilidade de repositório de memórias, a partir delas próprias e das suas interlocuções. Assim, o lugar-museu procurava ser uma não-existência percebida, um lugar de esquecimento, querendo passar sua presença em branco (neste caso no sentido cromático, também). Com isso, sublinhando a potência poética das obras, enfatizava-se a interligação entre memória e imaginação (Bachelard, 1978), ativadas pelas obras e reafirmando a ligação direta entre a imaginação do espectador e a imagem-arte.

A relação frente a frente do observador com a obra, ainda acompanhada pela passagem de um tempo linear, obra após obra, reforçava a posição de um visitante no museu. $O$ visitante veria o museu como um lugar que não era seu, apesar de poder ser de todo mundo, por seu caráter público, reforçando o comportamento de não privacidade nem de intimidade.

\section{No escuro}

As impressões dos museus-cubo-branco foram sendo, aos poucos, relativizadas com a absorção de obras em vídeo, cujas salas escuras se opunham à claridade "neutra" do branco. Entretanto, as caixas pretas, assim chamadas, passaram a demandar outras posturas. O tempo dedicado à obra, de modo a ser totalmente observada, deveria corresponder aos minutos propostos pelo 
artista. O visitante deveria ficar na sala por certo tempo, preferencialmente no escuro, para poder perceber a obra em toda a sua extensão. A relação de ver e ser visto foi relativizada, pois o ambiente escuro dificultava a observação de outra pessoa ou coisa para além da tela iluminada com imagens em movimento, gerando uma concentração na obra e permitindo uma sensação de anonimato.

Se nos salões claros, brancos e iluminados, a sensação de estar exposto obra e público - é superativada, nos cubos pretos, a densidade do escuro parece envolver e proteger o observador. Ele pode ficar à vontade, despido da sensação de vigilância. Nos cubos pretos, a posição sentada costuma ser incentivada, de modo a favorecer a apreensão da obra do começo ao fim, como uma seção de cinema. Diferente dos estabelecimentos comerciais, que entre uma seção e outra as luzes são acesas, as salas com vídeo-arte costumam estar constantemente no escuro e protegidas por cortinas na entrada, impossibilitando a percepção visual do tratamento das paredes, teto e piso. Sem luz, como saber da parede qual sua cor, sua textura, sua linguagem? Toda uma tradição decorativa do ambiente museal se tornou invisível. Por outro lado, as caixas montadas nos salões-galerias para a instalação da obra em vídeo eram normalmente executadas em compensado e pintadas de branco, configurando um cubo branco por fora e preto por dentro. O salão do museu ilumina o acervo, a caixa em branco, que só pode ser visto no escuro, pelo lado de dentro.

Especialmente quando se trata de instalação com imagens em movimento em várias posições com vídeos diferentes, a ideia de estar dentro da obra, em situação imersiva, ganha destaque, ao mesmo tempo em que continuam a ser telas na parede os monitores pendurados ou imagens projetadas. (fig. I0). Tudo permanece sob controle e o ambiente ainda segue os preceitos do museu cubo branco.

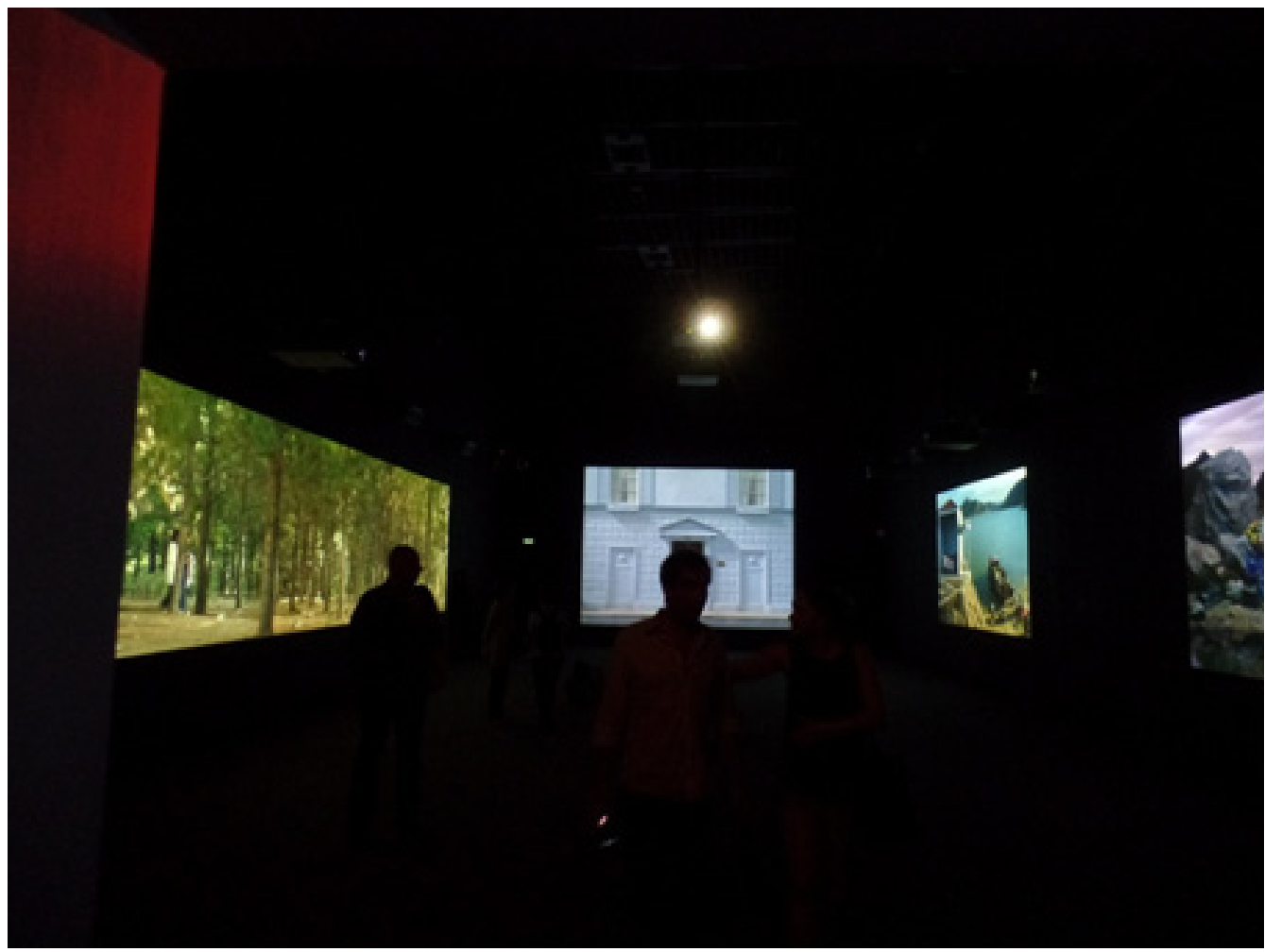

Fig. 10. Sortir au jour, 2002, instalação áudio/vídeo, ciclo de imagens projetadas em cinco partes, 35 minutos cada parte. Bill Violla. Exposição realizada no Grand Palais, Paris, março a julho de 2014. Fotografia da autora. 
Por mais que Hélio Oiticica tenha proposto recintos-obras, os Ninhos, em 1970, espaços para serem habitados e permitir introspecção, mais experimentais que expositivos (Oiticica apud Braga, 20I2: I63), permitindo a experiência estética como lazer descondicionado (crelazer), o que de fato predominou foi a postura institucional formal do museu como lugar de visita, de comportamentos controlados, trocas sociais cerimoniosas, um lugar para ir e vir.

\section{Dentro}

Apesar de o artista, por meio de linguagem própria, articular sua ideia sobre o mundo real e imaginado, seu derredor exterior e interior, quando sua obra se adentra no museu, acaba por ganhar um enquadramento que reconfigura a obra imaginada pelo primeiro criador, quando posta em exibição, fazendo dos curadores segundos co-autores. Como lembra Jérôme Glicenstein, não existe neutralidade em matéria de museografia, nem se pode pensar em neutralidade em matéria de espectador (2010, p.9-14).

Atualmente, quando se concorda com o esgotamento das classificações por tipos de museus baseados nas tipologias dos acervos, aceita-se que a arte não está no acervo, mas na relação. Esta relação se dá pelo modo como a obra é apresentada ao visitante, seja incorporada num ambiente residencial, a exemplo da period room, seja sobre o fundo branco liso.

Diante da perspectiva de olhar o museu como ambiente para arte, sua decoração, de fundo branco ou estampado ou colorido, permite visualizar outras possibilidades de história da arte, procurando contemplar o dar e o receber entre espectadores e os objetos expostos, como co-curadores do museu, sendo também o historiador da arte um outro co-curador a partir do momento que tece suas considerações diante das obras em acervos, as quais ganham outros enquadramentos a partir de suas reflexões. Sendo, portanto, um outro co-curador, seu embate com as obras estudadas poderia contemplar as ambiências que as cercam (seja em exibição ou em ostracismo nas reservas). Mas nem as molduras costumam ser mencionadas nas análises dos quadros, muito menos as ambiências que cercam as obras, suas paredes, e praticamente nunca os objetos, móveis e bibelôs que acompanham as telas, tendo em vista que os historiadores da arte parecem não freqüentar period rooms ou não admitem falar sobre decoração. $E$, assim, muitos assassinaram as ambiências e os objetos, de modo a calarem suas vozes.

Em pleno século $X X I$, ainda se pergunta sobre a possibilidade de o objeto possuir uma vitalidade inerente, visto o peso institucional dos museus a ambientá-los e enquadrá-los. O desafio de investigar a possibilidade de um conjunto de materiais possuir sua própria ontologia foi proposto por JF \& SON, um grupo experimental de moda, para a exposição After the Museum -The Home Front:American Design Now 201 $3^{3}$, no Musem of Arts and Design (MAD), em Nova York, após o programa de residência na mesma instituição. Fibras baratas foram utilizadas para montar a instalação The Mindfulness and Meditation of OurThings (fig. I I), com cortinas banais de nylon e esculturas de figuras humanas revestidas de pelúcia postas em determinadas contingências, de modo a que projetassem nos visitantes seu "glamour, contexto e significados". O efeito era conquistado pela experiência em caminhar entre as peças, visualizar o monitor, pendurado como um quadro, perceber a recontextualização dos têxteis em situação, tão presentes nas decorações das casas e nas period rooms. Entretanto, naquela composição ambiental desempenhavam outras funções. Eram decoração no museu. Eram uma espécie de period room contemporânea, sendo o ambiente decorativo o fundo e a figura.

${ }^{3} \mathrm{~A}$ exposição After the Museum reuniu instalações que buscassem esclarecer o componente conceitual de pesquisa na prática do design e examinassem o papel das instituições culturais, como os museus, em modelarem o design do passado, presente e futuro (After the museum, 2013). O MAD busca reunir diversas vozes, novas, radicais e não ortodoxas da arte e do design contemporâneos, procurando rever os limites que os separam. http://madmuseum.org/. 


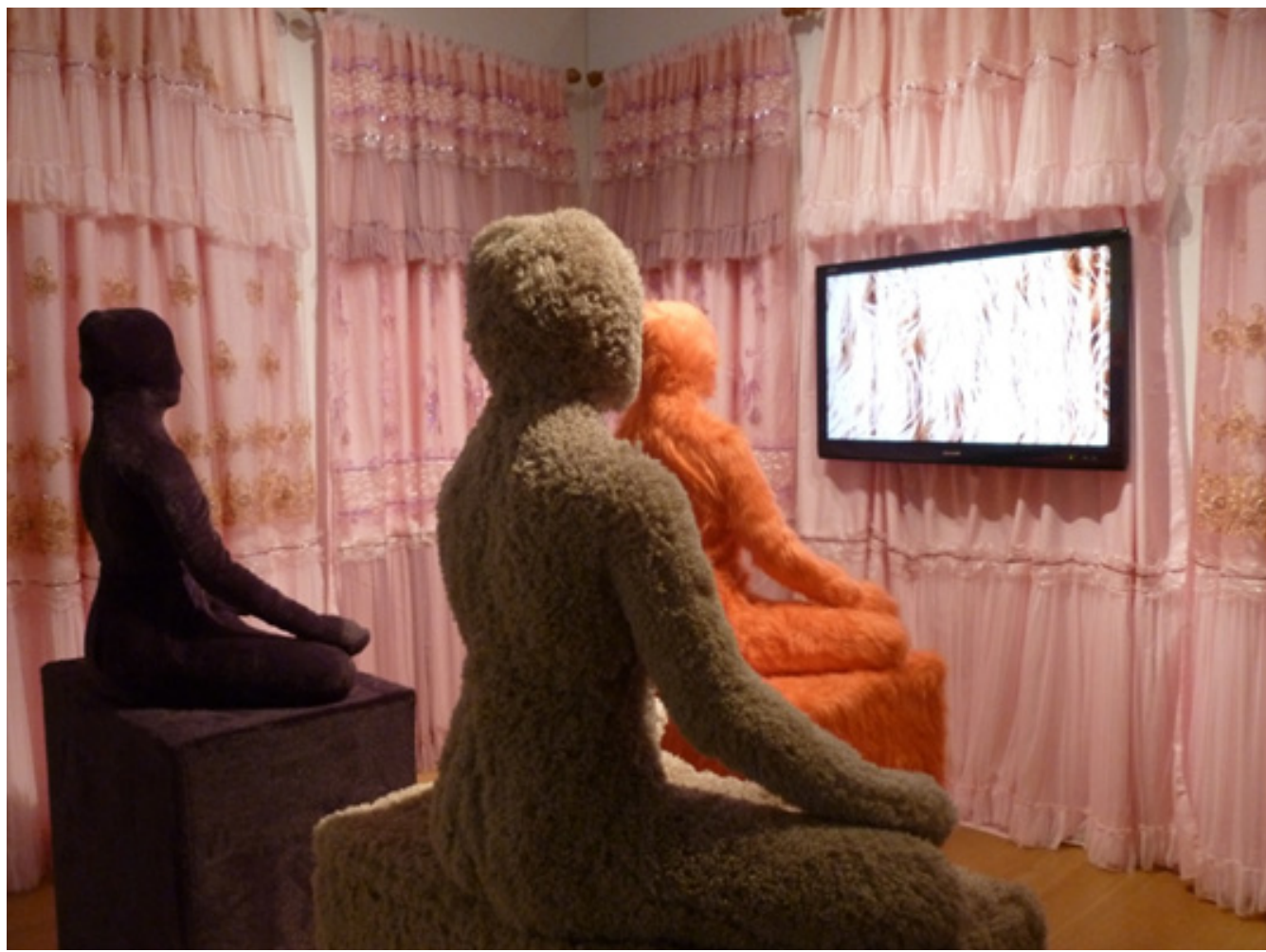

Fig. I I.JF \& SON. The Mindfulness and Meditation of Our Things, 2013. Várias midias. Museum of Art and Design (MAD), Nova York. Exposição decorrente do Programa de Residência em Design, 2013. Fotografia da autora.

Por mais que o museu que incorporou a obra mantivesse a lógica do cubo branco, JF \& SON valeu-se da prerrogativa da decoração para recriar o espaço e fazer do ambiente a sua obra.

As três figuras de pelúcia meditam em frente à tela, colocando-se na posição do público que introjeta e projeta ao mesmo tempo. $O$ cubo branco não está totalmente imperceptível, pois as cortinas cor-de-rosa com bordados e babados foram postas em intervalos, deixando frestas que permitiam entrever as paredes brancas. $O$ piso de madeira polido continuava lá, o teto branco com suportes de iluminação permanecia inerte. $\mathrm{Na}$ situação de supressão do tempo - tudo estava imóvel - só o vídeo concentrava a ideia de movimento e passagem de tempo, com suas imagens intermitentes, com flashes de padronagens e artefatos que se intercalavam na narrativa descontínua.As imagens visíveis na tela do monitor representavam a imaginação complexa decorrente da meditação sobre a própria cena - o estar no museu, sentado.

Feitos de têxteis, os cenários podiam se impregnar com as marcas das atuações dos participantes da cena. Os visitantes podiam se ver na representação dos três bonecos em tamanho natural em posição de lótus, em meditação, forrados de pelúcia, cada um com uma cor. Com suas texturas e cores, os objetos capturavam a atenção dos que olhassem para a situação e o apelo tátil superpunha-se ao visual.As figuras humanoides anunciavam uma permanência estavam no museu, ficavam nele, talvez lá morassem. E como era um lugar seu, decoraram ao seu gosto. Disfaçaram o branco e puseram cortinas cor-de-rosa.

A obra em questão nos faz refletir sobre os ambientes para arte e para a necessidade da conscientização e meditação sobre nossas coisas (de arte), alertando-nos para a potencialidade do museu decorado, mesmo dentro de um cubo branco, envolvente e includente, que provoca uma experiência de troca 
com os objetos, todos eles, na potência poética do seu conjunto. $\mathrm{Na}$ teatralidade da cena, apresenta-se um realismo especulativo, que recoloca o visitante dentro do museu, pondo-o imerso na ambiência, vivendo em uma ficção espacial, onde não se tem mais certeza se aquilo que vemos é arte ou decoração.Ao sairmos de lá, não conseguimos deixar de pensar que a obra não é só a tela (o monitor, no caso), mas tudo que a cerca. $A$ arte está sempre em algum lugar. $E$ o lugar também faz a obra.

\section{Referências}

AFTER THE MUSEUM. Museum of Arts and Design. New York: MAD, 2013. Disponível em: http://madmuseum.org/series/after-museum. Acessado em abril de 2016.

ATTFIELD. Judy. Wild things: the material culture of everyday life. Oxford: Berg, 2000. BACHELARD, Gaston. A poética do espaço. São Paulo: Martins Fontes, 1989.

BASTOS, Celina; FRANCO, Anísio. Para memória futura: interiores autênticos em Portugal. In: MALTA, Marize; MENDONÇA, Isabel (orgs.). Casas senhoriais Rio-Lisboa e seus interiores. Rio de Janeiro: EBA-UFRJ, Lisboa: IHA-FSCH-UNL / CEAD-ESAD-FRESS, 2013-2014.

BENJAMIN, Walter. O interior, o rastro. In: . Passagens. Belo Horizonte: Editora UFMG, São Paulo: Imprensa Oficial do Estado de São Paulo, 2009, p.247262.

BRAGA, Paula. Hélio Oiticica: museu é o mundo. In: OLIVEIRA, Emerson Dionisio; COUTO, Maria de Fátima Morethy (orgs.). Instituições da arte. Porto Alegre: Zouk, 2012, p.I59-I72.

COUTO, Maria de Fátima Morethy. Museus de arte e narrativas modernistas. In: OLIVEIRA, Emerson Dionísio; COUTO, Maria de Fátima M. (orgs.). Instituições da arte. Porto Alegre: Zouk, 20 I 2, p.I I-26.

CRARY, Jonhathan. Suspensions of perception. Attention, spectacle, and modern culture. Cambridge: MIT Press, 2000.

DESVALLÉS,André; MAIRESSE, François. Conceitos-chave de museologia. São Paulo: Comitê Brasileiro do Conselho Internacional de Museus, 2013.

DUNCAN, Sally Anne. From period room to public trust: the leadership in America. Curator: the Museum Journal, n. 45, issue 2, p.93-108, april 2002.

FUSS, Diana; SANDERS, Joel. An aesthethic headache: notes from the museum bench. In: BURTON, Johanna; COOKE, Lynne; McELHENY, Josiah (eds.). Interiors. Annandale-on-Hudson, NY: Sternberg Press, 20I2, p.64-79.

GLICENSTEIN, Jérôme. L'art: une histoire d'exposition. Paris : Presses Universitaires de France, 2010.

HARBISON, Robert. Eccentric spaces. Cambridge: MIT Press, 2000.

HASKELL, Francis. History and its images: art and the interpretation of the past. New Haven: London:Yale University Press, 1993.

KLONK, Charlotte. Spaces of experience: art gallery interiors from I800 to 2000. New Haven:Yale University Press, 2009.

LABBATE, Danielle. From period rooms to period environments: a look at how museums are redefining the scope of the period room. South Orange, NJ, 2007. Dissertation (Master of Arts in Museum Professions) - Seton Hall Univesity, South Orange, NJ, 2007. 
MAIRESSE, François; HURLEY, Cecilia. Élements d'expologie: matériaux pour une théorie du dispositif muséal. Media Tropes ejournal, vol. III, n. 2, p. I-27, 20 I 2. Disponível em: http:// www.mediatropes.com. Acesso em: fevereiro de 2016.

MALTA, Marize. $O$ olhar decorativo: ambientes domésticos em fins do século XIX no Rio de Janeiro. Rio de Janeiro: Mauad X/Faperj, 20I I.

Arte doméstica e imagem da nação: um olhar sobre os museus-casa de Rui Barbosa e de Benjamin Constant. Museu \& Interdisciplinaridade. Revista do Programa de Pós-Graduação em Ciência da Informação da Universidade de Brasília, Vol.I, nI, jan/jul de 20I2, p. I65-I83.

MATTOS, Cláudia Valladão de. Da palavra à imagem: sobre o programa decorativo de Affonso Taunay para o Museu Paulista. Anais do Museu Paulista, São Paulo, v.6/7, p. I23-145, 2003.

MAUAD, Ana Maria. Poses e flagrantes: ensaios sobre história e fotografias. Niterói: EdUFF, 2008.

MENESES, Ulpiano Bezerra de. Do teatro da memória ao laboratório da história: a exposição museológica e conhecimento histórico. Anais do Museu Paulista, São Paulo, v. 2, p.9-42, jan./dez. 1994.

MONTEBELLO, Philippe. Introduction. In: PECK, Amelia et al. Period rooms in the Metropolitan Museum of Art. 2 ed. New Haven: Yale University Press, New York: MET, 2004, p.9-I3.

O'DOHERTY, Brian. No interior do cubo branco: a ideologia do espaço da arte. São Paulo: Martins Fontes, 2002.

POMIAN, Krzysztof. Colecção. In: ENCILOPÉDIA EINAUDI. Memória/História. Porto: Imprensa nacional - Casa da Moeda, I 984, p. 5I-86, vol. I.

POULOT, Dominique. Museu e museologia. Belo Horizonte:Autêntica, 2013.

PRETI, Monica. Napoleão e a ideia de museu universal. In: CAVALCANTI, Ana; MALTA, Marize; PEREIRA, Sonia Gomes (orgs.). Coleções de arte: formação, exibição e ensino. Ri ode Janeiro: Rio Book's/Faperj, 20I5, p.7-24.

RICE, Charles. The emergence of the interior. Achitecture, modernity, domesticity. London: Routledge, 2007.

RICOUER, Paul. A história, a memória, o esquecimento. Campinas: Editora da Unicamp, 2007.

SHANKS, M. \& TILLEY, C.Y. Re-constructing archaeology: theory and practice. London: Routledge, 1992.

SPARKE, Penny. The modern interior. London: Reaktion Books, 2008.

TURAZZI, Maria Inez. Poses e trejeitos: a fotografia e as exposições na era do espetáculo (I 839- / 889). Rio de Janeiro: Rocco/Funarte, 1995.

WEST, Patricia. Domesticating history: the political origins of america's house museums. Washington, D.C.: Smithsonian Institution Press, 1999. 